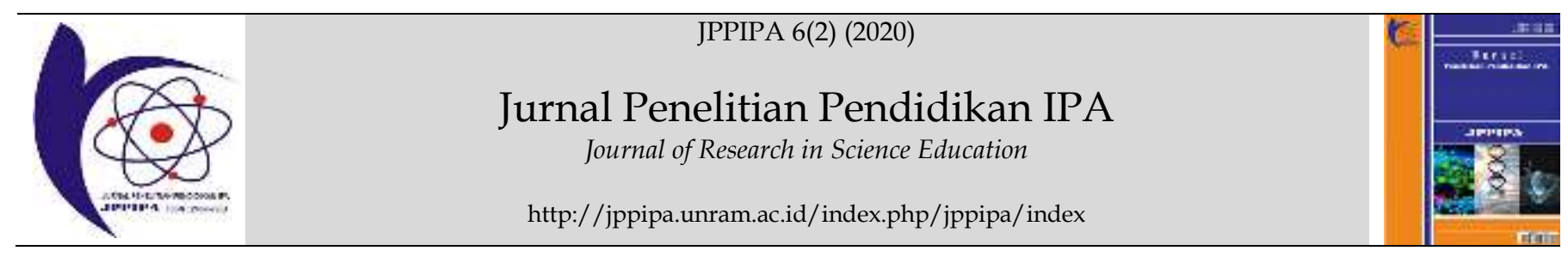

\title{
The Use of SASAMBO Culture in Learning Natural Product Chemistry to Support Traditional Health Tourism in Lombok and Sumbawa Islands
}

\author{
Aliefman Hakim ${ }^{1 *}$, Jamaluddin ${ }^{1}$, Syarifa Wahidah Al Idrus ${ }^{1}$, Muhammad Eka Putra Ramandha1
}

${ }^{1}$ FKIP Universitas Mataram, Mataram (NTB)

DOI: $\underline{10.29303 / \text { jppipa.v6i2.435 }}$

\section{Article Info}

Received : April 20th, 2020

Revised : June $12^{\text {th }}, 2020$

Accepted : June 16 $16^{\text {th }}, 2020$

\begin{abstract}
The SASAMBO (Sasak, Samawa, Mbojo) tribe has a variety of medicinal plants. The abundance of SASAMBO tribal medicinal plants can be used in learning the natural product chemistry which are expected to support traditional health tourism on the islands of Lombok and Sumbawa. Natural product chemistry examines the chemical content associated with the efficacy of a medicinal plant. This linkage can provide scientific support for the use of SASAMBO traditional medicinal plants. The method used in this research is the study of literature and questionnaires. Data sources came from public records, the results of questionnaire responses, and scientific articles related to SASAMBO traditional medicine. The results showed that there were various SASAMBO medicinal plants which were potentially used in the study of natural product chemistry with details, Lombok (Sasak) 43 species, Sumbawa (Samawa) 25 species, and Bima (Mbojo) 35 species. Some of these plant species are used for the treatment of diseases caused by viruses, so it has the potential to be used to treat corona outbreaks. Lombok and Sumbawa islands have abundant medicinal plants, this makes the two islands potential as a traditional health tourism destination.
\end{abstract}

Keywords: Medicinal plants; SASAMBO; Health Tourism.

Citation: Hakim, A., Jamaluddin., Al Idrus, S.W., \& Ramandha, M.E.P. (2020). The Use of SASAMBO Culture in Learning Natural Product Chemistry to Support Traditional Health Tourism in Lombok and Sumbawa Islands. Jurnal Penelitian Pendidikan IPA (JPPIPA), 6(2), 178-183. doi: https://doi.org/10.29303/jppipa.v6i2.435

\section{Introduction}

Indonesia, which is an archipelago, which certainly has a variety of tribes and traditions. The tradition is mainly in the health field, namely medicine. Clinically there are several medicinal plants used in medicine by the community. The plant was even planted in the home yard by the community. These medicinal plants include: Turmeric, Temu lawak, Kencur, Ginger, Galangal, Salam Leaves, Noni, Cat Mustache, Mahkotadewa, Soka, Jasmine, Papaya, Cocor Duck, Guava, Guava, Fruit Star, Betel, Lime, Katuk, Katuk, Turmeric White, Aloe Vera, Alang-alang, Starfruit Wuluh, Giring Giring, Sweet Potatoes, and
Beluntas (Jiwantoro, dkk 2017). One area in Indonesia that has a variety of medicinal plants is the West Nusa Tenggara (NTB) area. NTB has 2 large islands namely Lombok and Sumbawa. The two islands have 3 tribes namely the SASAMBO (Sasak Samawa Mbojo) tribe. The Sasak are on the island of Lombok, the Samawa and Mbojo are on the island of Sumbawa.

The SASAMBO tribe has medicinal plants used in the treatment of various diseases. There are various medicinal plants that can be used to treat diseases caused by viruses, so it has the potential to be used to treat corona outbreaks. The Samawa tribe has one of the most well-known traditional medicines, namely Sumbawa oil, said oil can cure various diseases and is 
used for generations by the people of Sumbawa. Sumbawa oil is made from a variety of plant species (Rahayu, 2016).

Traditional medical practices generally utilize various types of plants and animals for the treatment of diseases. Mild and severe diseases are treated by using herbs from certain types of plants and animals found around the yard of the house and in the forest. Such treatment can still be found among rural and urban communities (Sugiarto \& Wulansari, 2018). The development of SASAMBO traditional medicine can make NTB a health tourism destination.

The direction of local government policy especially in the tourism sector in NTB is sustainable tourism management. The management of sustainable tourism is guided by the 4 pillars of tourism, namely the development of destinations, marketing of tourism, industry and institutions. To support this, the provincial government issued various policies such as the Visit Sumbawa Lombok Program, Frendly Lombok and the Enchantment of Sumbawa as branding (Munir, U., et al. 2018).

Various cultural properties of SASAMBO medicinal plants can be used in learning Natural Product Chemistry (NPC). In terms of NPC, the efficacy of a medicinal plant is related to the content of secondary metabolites. NPC examines the type, distribution, and function of secondary metabolite compounds contained in organisms. The diversity of secondary metabolites comes from biodiversity. SASAMBO medicinal plant diversity is very high, so that it has the potential to advance the NPC.

\section{Method}

The method used in this research is the study of literature and questionnaires. Data sources came from public records, the results of questionnaire responses, and scientific articles related to SASAMBO traditional medicine. The data obtained were analyzed quantitatively and quantitatively. The data is processed through 3 three stages of analysis, namely data reduction, data display and conclusion.

\section{Result and Discussion}

Medicinal plants in the Sasak tribe are about 163 types of plants with different properties and ways of making and using drugs. In addition to Sasak tribe, Sumawa tribe also has various types of medicinal plants, there are about 40 medicinal plants found in Batu Bangka village, Sumbawa. The Mbojo tribe also has traditional medicinal plants, there are about 45 types of medicinal plants that are used for generations by the mbojo (Bima) tribe community (Ani, N. et al, 2018). The SASAMBO medicinal plants are shown in the Table 1.

Tabel 1. SASAMBO Medicinal plant data

\begin{tabular}{|c|c|c|c|c|c|}
\hline \multirow{2}{*}{$\begin{array}{l}\text { Regional } \\
\text { Name }\end{array}$} & \multirow{2}{*}{ No } & \multicolumn{3}{|c|}{ Name of Medicinal Plant } & \multirow{2}{*}{ Use } \\
\hline & & Local Name & Indonesian name & Latin name & \\
\hline \multirow{14}{*}{$\begin{array}{l}\text { Lombok } \\
\text { (Sasak) }\end{array}$} & 1 & Api-api & Api-api & Avicennia officinalis & Treat smallpox \\
\hline & 2 & $\begin{array}{l}\text { Ati beru } \\
\text { Ayan/kelicung }\end{array}$ & Ajang Kelicung & Diospyrus vilaria & $\begin{array}{l}\text { Treating tiwan and hernia } \\
\text { allergy "borot" }\end{array}$ \\
\hline & 3 & Banten & & A. grandiflora & Treat rheumatism and ulcers \\
\hline & 4 & Bebele & Maja & Aedle marmelos $(L)$ Correa & Treating gonorrhea and mumps \\
\hline & 5 & Barora & Katimaha & Klenhovia hospita & Treat thrush \\
\hline & 6 & Blandengan & $\begin{array}{l}\text { Lamtoro/petai } \\
\text { cina }\end{array}$ & $\begin{array}{l}\text { Leucaena glauca (lamk) de } \\
\text { wit benth }\end{array}$ & Anthelmintic \\
\hline & 7 & Bunga kumbi & & $\begin{array}{l}\text { Tabernaemontana } \\
\text { sphaerocarpa BI }\end{array}$ & Eye medicine \\
\hline & 8 & Daun bakung & $\begin{array}{l}\text { Daun bakung } \\
\text { putih }\end{array}$ & Crinum asiaticum & Wound medicine \\
\hline & 9 & Daun bebenyah & Daun akar aur-aur & Commelina diffusa Burm $f$. & $\begin{array}{l}\text { Medication for menstruation, } \\
\text { fever, and headaches }\end{array}$ \\
\hline & 10 & Daun empet-empet & Daun sisik betook & $\begin{array}{l}\text { Desmodium triflorum }(L) \\
\text { DC }\end{array}$ & $\begin{array}{l}\text { Medication for wounds and } \\
\text { diarrhea }\end{array}$ \\
\hline & 11 & $\begin{array}{l}\text { Daun geronong } \\
\text { bodok }\end{array}$ & & $\begin{array}{l}\text { Crotalaria usaramoensis } \\
\text { Baker } f\end{array}$ & Red eye drops \\
\hline & 12 & Daun pecut jaran & Daun pecut kuda & $\begin{array}{l}\text { Stachytarpheta jamaicencis } \\
\text { (L) Vahl }\end{array}$ & Cough and tonsill medicine \\
\hline & 13 & Daun seripa & $\begin{array}{l}\text { Daun tempuh } \\
\text { wiyang }\end{array}$ & Emilia sonchifolia $(L) D C$ & Wound medicine \\
\hline & 14 & Daun Sesapa & Daun sembung & Blumea balsamifera $(L) D C$ & Treating rheumatism, joints, \\
\hline
\end{tabular}




\begin{tabular}{|c|c|c|c|c|c|}
\hline \multirow{32}{*}{$\begin{array}{l}\text { Regional } \\
\text { Name }\end{array}$} & \multirow{2}{*}{ No } & \multicolumn{3}{|c|}{ Name of Medicinal Plant } & \multirow{2}{*}{ Use } \\
\hline & & Local Name & Indonesian name & Latin name & \\
\hline & & & & & $\begin{array}{l}\text { influenza, diarrhea and } \\
\text { menstrual pain }\end{array}$ \\
\hline & 15 & Daun Srikaya Bayan & Daun srikaya & Annona squamosal L. & $\begin{array}{l}\text { Treat wounds, ulcers, boils, } \\
\text { coughs and fever }\end{array}$ \\
\hline & 16 & $\begin{array}{l}\text { Daun telingan } \\
\text { bangket }\end{array}$ & $\begin{array}{l}\text { Daun pegagan } \\
\text { hijau }\end{array}$ & Centella asiatica (L) Urban & $\begin{array}{l}\text { Medicine for fever and urine } \\
\text { laxative }\end{array}$ \\
\hline & 17 & Daun terinjing & Daun tempuyung & sonchus oleraceus $L$ & Wound medicine \\
\hline & 18 & Entut-entut & Daun kentut & Paederia foetida $L$ & $\begin{array}{l}\text { Treat stomach aches and back } \\
\text { pain }\end{array}$ \\
\hline & 19 & Geguthu & Kanyere badak & Bridelia stipularis $(L) B I$ & Treating dysentery \\
\hline & 20 & Gambir & Gambir & Uncaria gambir & Treating dysentery \\
\hline & 21 & Grepek & Dadap & Erythrina sp & Treat smallpox \\
\hline & 22 & Inggu & Asafetida & Ferula asa-foetida & Treating migraines \\
\hline & 23 & Jambokan & Patikan kebo & Euphorbia hirta L. & $\begin{array}{l}\text { Medication for wounds and } \\
\text { dysentery }\end{array}$ \\
\hline & 24 & Jarak & Jarak & Jatropha curcas L & $\begin{array}{l}\text { Medication for worms, } \\
\text { flatulence and wounds }\end{array}$ \\
\hline & 25 & Jeringo & Jeringau & Acorus calamus & Treat stomach aches and pain \\
\hline & 26 & Jeliti & Mentaok & Wrightia javanica & Treat rheumatism \\
\hline & 27 & Jowet & $\begin{array}{l}\text { Jamblang/jambu } \\
\text { keeling/duwet }\end{array}$ & Eugenia cumini & $\begin{array}{l}\text { Treat stomach aches, silent } \\
\text { dysentery and ulcers }\end{array}$ \\
\hline & 28 & Kekosok & Ardisia & Ardisia javanica DC & Treating smallpox \\
\hline & 29 & Kelokos udang & Daun salam & Syzgium polyanthum & Treating scaly skin \\
\hline & 30 & Kendal & Kendal & Cordia obliqua willd & Fever medicine \\
\hline & 31 & Kethuk & Bira & Alocasia sp & $\begin{array}{l}\text { Treat snake bites, malignant } \\
\text { ulcers and nerve rashes }\end{array}$ \\
\hline & 32 & $\begin{array}{l}\text { Kulit batang } \\
\text { durenan }\end{array}$ & & $\begin{array}{l}\text { Knema sumatrana (blume) } \\
\text { W.J. de wilde. }\end{array}$ & Malaria medicine \\
\hline & 33 & Lebui & $\begin{array}{l}\text { Kacang } \\
\text { gude/kacang } \\
\text { kayo }\end{array}$ & Cajanus cajan & Treating urinary stones \\
\hline & 34 & Daun lekong & Daun kemiri & Aleurites moluccana $(L)$ & Treat silu and cold allergies \\
\hline & 35 & Lembukik bulu & Pohon ara & Ficushispida L & Shortness of breath medicine \\
\hline & 36 & Lita & Pulai & Alstonia scholaris & Treat ulcers \\
\hline & 37 & Meniran & Meniran & Phyllanthus niruri & $\begin{array}{l}\text { Treat kidney, diabetes and } \\
\text { eczema }\end{array}$ \\
\hline & 38 & Randu & $\begin{array}{l}\text { Kapuk } \\
\text { randu/kapuk }\end{array}$ & Ceiba pentandra & Treating tartar \\
\hline & 39 & Sereto & Serut pagar & Ehretia microphyla & Treat malaria \\
\hline & 40 & Suren & Surian & Toona sureni & Treat boils \\
\hline & 41 & Songgo langit & Gletang & Tridax procumbens & $\begin{array}{l}\text { Treat lumbago, kidney, high } \\
\text { blood pressure and cholesterol }\end{array}$ \\
\hline & 42 & Tanaman sumangge & Daun asam kecil & Oxalis corniculata $L$ & Cough medicine \\
\hline & 43 & Wareng & Wareng & Gmelina asiatica $L$ & $\begin{array}{l}\text { Medicine for itching and } \\
\text { earaches }\end{array}$ \\
\hline \multirow[t]{8}{*}{$\begin{array}{l}\text { Sumbawa } \\
\text { (Samawa) }\end{array}$} & 1 & Aren & Enau & Arenga pinnata Merr & $\begin{array}{l}\text { Treat kidney stones and canker } \\
\text { sores }\end{array}$ \\
\hline & 2 & Cabe jawa & Cabai jawa & Piper etrofractum & $\begin{array}{l}\text { Treat toothache and enter } \\
\text { angina }\end{array}$ \\
\hline & 3 & Ceplukan & Ceplukan & Physalis Angulata L & Treat hypertension and diabetes \\
\hline & 4 & Dadap & Dadap & Phyllanthus acidus $L$ & $\begin{array}{l}\text { Treating fever, intestinal worms } \\
\text { and launching menstruation in } \\
\text { women }\end{array}$ \\
\hline & 5 & Gadung & Gadung & D. hispida & Treating leprosy, and calluses \\
\hline & 6 & Gambir & Gambir & Uncaria gambir hunter $R$ & Treat thrush and diarrhea \\
\hline & 7 & Gayam & Gayam & Inocarpus Fagiferus & Diarrhea Medication \\
\hline & 8 & Kecubung & Kecubung & Datura suaveolens Humb & Treating rheumatic asthma and \\
\hline
\end{tabular}




\begin{tabular}{|c|c|c|c|c|c|}
\hline \multirow{20}{*}{$\begin{array}{l}\text { Regional } \\
\text { Name }\end{array}$} & \multirow{2}{*}{ No } & \multicolumn{3}{|c|}{ Name of Medicinal Plant } & \multirow{2}{*}{ Use } \\
\hline & & Local Name & Indonesian name & Latin name & \\
\hline & & & & & back pain \\
\hline & 9 & Kenanga & Kenanga & Cananga odorata & $\begin{array}{l}\text { Treating shortness of breath, } \\
\text { malaria, bronchitis, scabies, and } \\
\text { jaundice }\end{array}$ \\
\hline & 10 & Kesambi & Kesambi & Schleichera Oleosa Merr & Treating scabies and scars \\
\hline & 11 & Kluwih & Kluwih & Artocarpus camansi & Treat toothache and cholesterol \\
\hline & 12 & Kumis kucing & Kumis kucing & Orthosiphon Aristatus & $\begin{array}{l}\text { Treating kidney stones and } \\
\text { diabetes }\end{array}$ \\
\hline & 13 & Mangkokan & Mangkokan & Polyscias Scutellaria & $\begin{array}{l}\text { Treating inflammation of the } \\
\text { breast and difficult to urinate }\end{array}$ \\
\hline & 14 & Mengkudu & Mengkudu & Morinda citrifolia $L$ & $\begin{array}{l}\text { Treat hypertension and } \\
\text { inflammation of the intestine }\end{array}$ \\
\hline & 15 & Meniran & Meniran & Phyllanthus Niruri L & $\begin{array}{l}\text { Treating gonorrhea, } \\
\text { inflammation of the stomach } \\
\text { and malaria }\end{array}$ \\
\hline & 16 & Merambung & Merambung & Vernonia arborea & Treat thrush and fever \\
\hline & 17 & Mindi & Mindi & Melia adezarach & $\begin{array}{l}\text { Treating high blood pressure } \\
\text { and intestinal worms }\end{array}$ \\
\hline & 18 & Mundu & Mundu & Garcinia, spp & Treat mumps and wounds \\
\hline & 19 & Patikan kebo & Petikan kebo & Euphorbia Hirta L & $\begin{array}{l}\text { Treating strep throat and } \\
\text { bronchitis }\end{array}$ \\
\hline & 20 & Randu & Randu & Ceiba pentandra & $\begin{array}{l}\text { Treat hemorrhoids, dysentery } \\
\text { and heartburn }\end{array}$ \\
\hline & 21 & Saga & Saga & Abrus precatorius & $\begin{array}{l}\text { Medication for thrush and } \\
\text { tonsils }\end{array}$ \\
\hline & 22 & Sambung nyawa & Sambung nyawa & Gynura procumbens & $\begin{array}{l}\text { Treating cysts, cancer and } \\
\text { tumors }\end{array}$ \\
\hline & 23 & Serut & serut & Streblus asper,,Lour & Hepatitis drugs and boils \\
\hline & 24 & Srikaya groso & Srikaya & annanasquamosa & $\begin{array}{l}\text { Treating intestinal worms and } \\
\text { digestive disorders }\end{array}$ \\
\hline & 25 & Tanjung & Tanjung & Mimusops elengi $L$ & Treat headaches and fever \\
\hline \multirow[t]{17}{*}{$\begin{array}{l}\text { Bima } \\
\text { (Mbojo) }\end{array}$} & 1 & Anggo & Kersen & Muntingia calabura & $\begin{array}{l}\text { Treating gout, stomach cramps } \\
\text { and antioxidants }\end{array}$ \\
\hline & 2 & Dungga Mbudi & Jeruk purut & Citrus hystrix & Treat joints and gout \\
\hline & 3 & Dungga Ncia & Jeruk nipis & Citrus auratifolia & \\
\hline & 4 & Duwe & Jamblang & Eugenia cumini & $\begin{array}{l}\text { Treat stomach aches, silent } \\
\text { dysentery and ulcers }\end{array}$ \\
\hline & 5 & Garoso Jawa & Sirsak & Annona muricata & Treating cholesterol and gout \\
\hline & 6 & Garoso mbudi & Srikaya & Annona squamosal & $\begin{array}{l}\text { Treating intestinal worms and } \\
\text { digestive disorders }\end{array}$ \\
\hline & 7 & Golka & Kirinyuh & Chromolaena odorata & Treat ulcer and vertigo \\
\hline & 8 & Jambu Doro & Jambu batu & Psidium guajava & $\begin{array}{l}\text { Smooth the digestive tract and } \\
\text { increase blood platelets }\end{array}$ \\
\hline & 9 & Kajabu & Sintrong & Crassocephalum & Prevents cancer \\
\hline & 10 & Kajara Sarui & Bayam duri & Amaranthus spinosus & $\begin{array}{l}\text { Treating gonorrhea and } \\
\text { hemorrhoids }\end{array}$ \\
\hline & 11 & Kakapi Na'e & Ketapeng cina & Cassia alata & $\begin{array}{l}\text { Treating eczema, tinea } \\
\text { versicolor and ringworm }\end{array}$ \\
\hline & 12 & Kambesi & Katuk & Sauropus androgynous & Treat wounds and anemia \\
\hline & 13 & Kana'a & Patikan kebo & Euphorbia hirta & $\begin{array}{l}\text { Treating strep throat and } \\
\text { bronchitis }\end{array}$ \\
\hline & 14 & Kana'a Keta & Patikan cina & Euphorbia thymifolia & $\begin{array}{l}\text { Treating dysentery and } \\
\text { hemorrhoids }\end{array}$ \\
\hline & 15 & Mahoni & Mahoni & Swietenia mahagoni & $\begin{array}{l}\text { Treating constipation and } \\
\text { menstrual pain }\end{array}$ \\
\hline & 16 & Mangge & Asam & Tamarindus indica & $\begin{array}{l}\text { Streamlining the digestive } \\
\text { system }\end{array}$ \\
\hline & 17 & Nceha & Tapak Liman & Elephantopus scaber & $\begin{array}{l}\text { Treating inflammation, } \\
\text { influenza and vaginal discharge }\end{array}$ \\
\hline
\end{tabular}




\begin{tabular}{|c|c|c|c|c|c|}
\hline \multirow{2}{*}{$\begin{array}{l}\text { Regional } \\
\text { Name }\end{array}$} & \multirow{2}{*}{ No } & \multicolumn{3}{|c|}{ Name of Medicinal Plant } & \multirow{2}{*}{ Use } \\
\hline & & Local Name & Indonesian name & Latin name & \\
\hline & 18 & Nonu & Mengkudu & Morinda citrifolia & $\begin{array}{l}\text { in women } \\
\text { Treat hypertension and } \\
\text { inflammation of the intestine }\end{array}$ \\
\hline & 19 & Ntonu & Lempuyang Gajah & Zingiber zerumbet & Treat allergies and infections \\
\hline & 20 & Pataha & Kemangi Hutan & Kemangi Hutan & $\begin{array}{l}\text { Treating colds, headaches and } \\
\text { intestinal worms }\end{array}$ \\
\hline & 21 & Pate & Lamtoro & Leucaena leucocephala & $\begin{array}{l}\text { Treating intestinal worms and } \\
\text { ulcers }\end{array}$ \\
\hline & 22 & Pawu Keta & Bandotan & Ageratum conyzoides & Treat ulcers \\
\hline & 23 & Rera sawa doro & Lidah Ular & Hedyotis corymbosa & $\begin{array}{l}\text { Decay urine and maintain } \\
\text { kidney health }\end{array}$ \\
\hline & 24 & Rondu & Bungur & Lagerstromeia speciosa & $\begin{array}{l}\text { Treating toothache and } \\
\text { coughing up blood }\end{array}$ \\
\hline & 25 & Ro'o Parongge & Kelor & Moringa oleifera & $\begin{array}{l}\text { Treat cholesterol and nourish } \\
\text { the eyes }\end{array}$ \\
\hline & 26 & Ro'o Praja & Cincau rambat & Cyclea barbata Miers & Treat fever and diabetes \\
\hline & 27 & Sabia & Cabai Hutan & Piper retrofractum & $\begin{array}{l}\text { Treat anemia, cholera and } \\
\text { bronchitis }\end{array}$ \\
\hline & 28 & Sambi & Kesambi & Schleichera oleosa & $\begin{array}{l}\text { Treating eczema, scabies and } \\
\text { ulceration }\end{array}$ \\
\hline & 29 & Soka & Krokot & Portulaca sp. & Maintain eye health \\
\hline & 30 & Songga & Bidara Laut & Strychnos lucida & Treat rheumatism and wounds \\
\hline & 31 & Supa & Secang & Caesalpinia sappan & Treat diabetes \\
\hline & 32 & Tamba & Brotowali & Tinospora crispa & Treating gout and diabetes \\
\hline & 33 & Tatanga & Jarak Pagar & Jatropha curcas & $\begin{array}{l}\text { Treat wounds, colds and } \\
\text { flatulence }\end{array}$ \\
\hline & 34 & Tula & Pulai & Alstonia scholaris & Treat ulcers \\
\hline & 35 & $\mathrm{U}^{\prime} \mathrm{a}$ & Pinang & Areca catechu & $\begin{array}{l}\text { Treating intestinal worms and } \\
\text { glaucoma }\end{array}$ \\
\hline
\end{tabular}

Source: Public records, questionnaire responses, and scientific articles (Yamin, et al., 2018; Jannah \& Safnowandi 2018)

The data in Table 1 shows the diversity of traditional medicinal plants owned by the SASAMBO community. The diversity of medicinal plants provides evidence that the rich nature of Indonesia. Various medicinal plants, indicating the efficacy of these medicinal plants. Ranging from treatment for minor illnesses to treatment for severe illness. All parts of the medicinal plant can be processed based on a hereditary prescription from the ancestors. Several species of plants are used to treat diseases caused by viruses, so it has the potential to be used to treat corona outbreaks.

Literature studies show that various parts of the SASAMBO medicinal plant can be formulated as a healing herb, namely:

\section{Leaves}

The process of compounding the leaves of medicinal plants as a healing herb, namely: (1) the leaves are ground, (2) given a little water and placed on the body that feels pain. As for other ways of processing medicinal plant leaves namely. (1) boiled leaves of medicinal plants, (2) then drink the water. (Jannah, \& Sasnowandi, 2018).
2. The stem

The process of compounding the stems of medicinal plants as a nutritious concoction, is done in a way that is, (1) the stems of medicinal plants are boiled in a container filled with water and (2) the boiled water is drunk (Ariadi, L. M, 2017).

3 pieces

The processing of medicinal plants is carried out in several ways, namely: (1) the fruit is ground (mashed) (2) then filtered the fruit that has been mashed (3) add water to the screening process. (Yamin $\mathrm{M}$, et al, 2018).

4. Root

The process of processing the roots of medicinal plants is carried out in several ways, namely: (1) the roots are boiled in a container filled with water (2) the boiled water is drunk. (Jannah, \& Ridwan, 2017). Flower are usually used without being processed and directly used by the community. (Sugiarto, \& Wulansari, 2018).

The concoctions produced by the SASAMBO community are diverse and nutritious. If the medicinal plants and concoctions of the SASAMBO community 
are well managed, they can become a separate income for the SASAMBO community. This management can be in the form of community empowerment and the provision of facilities in the development of health tourism (herbal). Herbal tourism is one of the attractive tourist destinations for tourists because of its natural beauty, herbal products, and the friendliness of its people (Waruwu, et al, 2020).

The SASAMBO medicinal plants described above can be used in learning Natural Product Chemistry (NPC). NPC examines the type, distribution, and function of secondary metabolite compounds contained in organisms. The secondary metabolite compounds referred to are terpenoids, steroids, phenyl propanoids, polyketides, flavonoids, and alkaloids.

Learners can do a project-based learning by isolating secondary metabolite compounds found in SASAMBO medicinal plants. Learning projects can vary each year by replacing plant species that have been isolated from their chemical contents. This activity will give students the opportunity to improve higher order thinking skills such as critical thinking skills, creative thinking skills, decision making skills, and problem solving skills related to the process of isolating secondary metabolites from SASAMBO medicinal plants.

\section{Conclusion}

The diverse medicinal plants of the SASAMBO community and the effective concoction of concoctions can make the island of Lombok and Sumbawa as a health tourism destination (herbal). The various SASAMBO medicinal plant species can be used in the study of natural product chemistry (NPC). NPC examines the chemical content associated with the efficacy of a medicinal plant. These skills can provide scientific support for the use of SASAMBO traditional medicinal plants.

\section{References}

Ani, N., Rohyani, S.I., \& Maulana. (2018). Pengetahuan Masyarakat Tentang Jenis Tumbuhan Obat Di Kawasan Taman Wisata Alam Madapangga Sumbawa. J. Pijar MIPA. 13 (2), 160-166. DOI: http://dx.doi.org/10.29303/ipm.v13i2.751

Ariadi, L.M. (2017). Naskah Pengobatan Dan Pertumbuhan Islam Di Indonesia Tengah. Proceedings ANCOMS. 979-988.

Jannah. H \& Ridwan. (2017). Pengobatan Tradisional Suku Sasak Berbasis Ilmiah Di kabupaten
Lombok Barat. Bioscientist: Jurnal Ilmiah Biologi. 1 (2), 116-125. doi: https://doi.org/10.33394/bjib.v1i2.790

Jannah, H \& Safnowandi. (2018). Identifikasi jenis tumbuhan obat tradisional di Kawasan hutan olat cabe desa batu bangka kecamatan moyo hilir kabupaten sumbawa besar. Bioscientist: Jurnal Ilmiah Biologi. 6 (2), 145-172. doi: https://doi.org/10.33394/bjib.v6i2.2457

Jiwantoro, Y.A., Syah, S.O., \& Dewi, R.A. (2017). Optimalisasi "Bu Pur" Sebagai Upaya Pencegahan dan Pengobatan Penyakit Degeneratif Pada Lansia Di Dusun Karang Bayan Barat Desa Karang Bayan Kecamatan lingsar Lombok Barat. Jurnal Pengabdian Masyarakat Sasambo. http://jkp.poltekkesmataram.ac.id/index.php/PKS/inde $\underline{x}$

Munir, U., Dimyati, K., \& Absori. (2018). Implementasi Kebijakan Pengembangan Pariwisata di Pulau Lombok. Jurnal Imiah Hukum. 128-137. doi: https://doi.org/10.33319/yume.v4i2.13

Rahayu, S. (2016). Pariwisata Kreatif; Strategi Menghadapi Masyarakatekonomi Asean (MEA). Prosiding Seminar Nasional Pendidikan 2016“Revitalisasi Budaya Lokal dalam Menghadapi Tantangan Pendidikan pada Era Masyarakat Ekonomi ASEAN (MEA)"

Sugiarto. S \& Wulansari, D. (2018). Kategori Dan Ekspresi Lingustik Obat-Obatan Tradisional Masyarakat Sumbawa. Prosiding Seminar Nasional Lembaga Penelitian dan Pendidikan (LPP) Mandala. 411-415

Waruwu, D., Erfiani, N.M.D., Darmawijaya, I.P., \& Kurniawati, N.S.E. (2020). Pengembangan Tanaman Herbal Sebagai Destinasi Wisata di Desa Catur, Kintanami, Bali. Jurnal Panrita Abadi. 4 (1), 1-10

Yamin, M., Burhanudin, Jamaluddin, Nasruddin. (2018). Pengobatan Dan Obat Tradisional Suku Sasak Di Lombok. Jurnal Biologi Tropis. 18 (1), 112. doi: http://dx.doi.org/10.29303/jbt.v18i1.560 